\title{
Synthesis and Biological Evaluation of Kojyl Thioether Derivatives as Tyrosinase Inhibitors
}

\author{
Ho Sik Rho, ${ }^{*}$ Heung Soo Baek, Soo Mi Ahn, Myung Kyoo Kim, ${ }^{\dagger}$ Amal Kumar Ghimeray, ${ }^{\ddagger}$ Dong Ha Cho, ${ }^{\ddagger}$ \\ and Jae Sung Hwang ${ }^{\S, *}$ \\ R\&D Center, AmorePacific Corporation, Yongin 446-729, Korea. E-mail: thiocarbon@freechal.com \\ ${ }^{\dagger}$ Samkyung Costech Co., Ltd., Suwon 443-734, Korea \\ ${ }^{\ddagger}$ Department of Bio-Health Technology, College of Biomedical Science, Kangwon National University, \\ Chuncheon 200-701, Korea \\ ${ }^{\S}$ Department of Genetic Engineering and Skin Biotechnology Center, College of Life Science, Kyung Hee University, \\ Yongin 446-701, Korea. *E-mail: jshwang@khu.ac.kr \\ Received April 5, 2010, Accepted June 7, 2010
}

Key Words: Kojyl thioether derivatives, Tyrosinase inhibitor, Depigmenting activity

Tyrosinase $^{1}$ is a copper-containing enzyme that is widely distributed in nature. This enzyme catalyzes two distinct reactions involved in melanin biosynthesis. Both the hydroxylation of L-tyrosine to L-dopa and the subsequent oxidation of L-dopa to dopaquinone are catalyzed by tyrosinase. These processes are involved in melasma ${ }^{2}$ and lentigo, ${ }^{3}$ both of which are disorders that result in the abnormal accumulation of melanin. Therefore, tyrosinase inhibitors have attracted attention as important cosmetic materials and depigmenting agents for treating hyperpigmentation. Hydroquinone ${ }^{4}(\mathbf{1})$ is well known depigmenting agent that is used to reduce melanin content by inhibition of tyrosinase. Although hydroquinone exhibits highly potent depigmenting activity, its application in cosmetics is restricted because of its severe side effects such as melanocyte destruction, irritative dermatitis, and contact dermatitis. To overcome this disadvantage, its glycoside derivative, $\operatorname{arbutin}^{5}(\mathbf{2})$, was synthesized and evaluated for its efficacy. Although arbutin has fewer side effects, it also has lower depigmenting activity. Kojic $\operatorname{acid}^{6}(\mathbf{3})$ is another well known tyrosinase inhibitor. In anticipation of synergistic activity, two active tyrosinase inhibitors (hydroquinone and kojic acid) were conjugated with the ether group. ${ }^{7}$ However, it did not exhibit sufficiently potent inhibitory activity. In this study, we synthesized four kojyl thioether derivatives (7a-7d). Recently, dimeric kojic acid derivatives $^{8}$ containing the thioether group have exhibited potent depigmenting activities. Sulfoxides (7e-7g) and sulfone derivatives (7h-7j) were also developed by oxidizing the thioether group. We evaluated the tyrosinase inhibitory activity of ten kojic acid derivatives and investigated their structure-activity relationships. Among them, 2-((4-hydroxyphenylthio)methyl)-5-hydroxy-4H-pyran-4-one (7b) exhibited the most potent tyrosinase inhibitory activity. Its depigmenting effect on a melanocyte cell

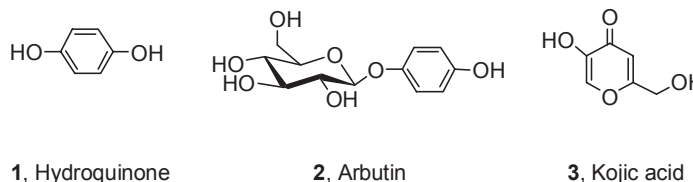

Figure 1. Structures of depigmenting agents. line was also investigated herein.

The synthetic pathways of kojic acid derivatives are shown in Scheme 1. Kojic acid derivatives (7a-7d) were synthesized by the condensation of kojyl chloride $\mathbf{5}$ or 5-methoxy kojyl chloride 6 with benzenethiols in presence of triethylamine. Kojic acid $\mathbf{3}$ was reacted with thionyl chloride to afford kojyl chloride 5. Then, kojyl chloride $\mathbf{5}$ was treated with dimethylsulfate in $\mathrm{K}_{2} \mathrm{CO}_{3}$ /acetone at reflux to afford a 5-methoxy kojyl chloride 6. Kojyl chloride 5 or 5-methoxy kojyl chloride 6 was reacted with benzenethiols in presence of triethylamine in tetra-



Scheme 1. Reaction conditions: (a) $\mathrm{SOCl}_{2}$, DMF, rt; (b) dimethylsulfate, $\mathrm{K}_{2} \mathrm{CO}_{3}$ /acetone, reflux; (c) benzenethiols, triethylamine, THF; (d) MCPBA, methylene chloride, rt; (e) oxone, $\mathrm{MeOH} / \mathrm{H}_{2} \mathrm{O}$, rt.

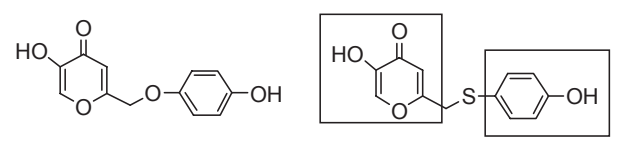

4

$7 b$ 
Table 1. Effect of the new kojic acid derivatives (7a-7j), kojic acid, and arbutin

\begin{tabular}{cc||cr}
\hline Compounds & $\mathrm{IC}_{50}{ }^{a}$ & Compounds & \multicolumn{1}{c}{$\mathrm{IC}_{50}{ }^{a}$} \\
\hline $\mathbf{7 a}$ & $2.08 \mu \mathrm{M}$ & $\mathbf{7 g}$ & $21.04 \mu \mathrm{M}$ \\
$\mathbf{7 b}$ & $0.54 \mu \mathrm{M}$ & $\mathbf{7 h}$ & $20.23 \mu \mathrm{M}$ \\
$\mathbf{7 c}$ & $2.24 \mu \mathrm{M}$ & $\mathbf{7 i}$ & $6.21 \mu \mathrm{M}$ \\
$\mathbf{7 d}$ & $>200 \mu \mathrm{M}$ & $\mathbf{7 j}$ & $18.02 \mu \mathrm{M}$ \\
$\mathbf{7 e}$ & $25.01 \mu \mathrm{M}$ & Kojic acid & $48.52 \mu \mathrm{M}$ \\
$\mathbf{7 f}$ & $3.25 \mu \mathrm{M}$ & Arbutin & $250.12 \mu \mathrm{M}$ \\
\hline
\end{tabular}

${ }^{a}$ Values were determined from the logarithmic concentration-inhibition curves and are given as the mean values of the results of three experiments.

hydrofurane to afford the corresponding thioether derivatives (7a-7d). The thioether derivatives $(\mathbf{7 a - 7} \mathbf{c})$ were reacted with MCPBA ( $m$-chloroperbenzoic acid) in methylene chloride to produce sulfoxide derivatives $(\mathbf{7 e - 7 g})$. Sulfone derivatives (7h-7j) were obtained by the treatment of thioether derivatives (7a-7c) with oxone in a mixture of $\mathrm{MeOH} / \mathrm{H}_{2} \mathrm{O}$.

Initially, the inhibitory activities of our synthetic kojic acid derivatives on mushroom tyrosinase were investigated using kojic acid and arbutin as positive controls. The results are exhibited in Table 1.

5-Hydroxy-2-((phenylthio)methyl)-4H-pyran-4-one (7a) exhibited potent inhibitory activity against tyrosinase $\left(\mathrm{IC}_{50}=\right.$ $2.08 \mu \mathrm{M})$. When an additional hydroxyl group was added at the para position of the aromatic ring, the inhibitory activity was dramatically increased $\left(\mathrm{IC}_{50}\right.$ of $\left.7 \mathbf{b}=0.54 \mu \mathrm{M}\right)$. Compound $7 \mathbf{b}$ consists of two active sites, namely, the kojic acid moiety and the 4-hydroxy aromatic ring. On the other hand, compound $\mathbf{7 c}$, which has a methoxy group at the para position, was found to exhibit activity similar to that of compound $\mathbf{7 a}$. When the 5 -hydroxy group of compound $\mathbf{7 b}$ was methylated, its activity was completely lost. These results reveal that the enolic hydroxyl group of the kojic acid moiety may be more important than the aromatic hydroxyl group for the inhibition of tyrosinase. In the next set of experiments, we changed the sulfur functional group of compounds $7 \mathbf{a}-\mathbf{7} \mathbf{c}$. Interestingly, sulfoxide derivatives (7e-7g) exhibited decreased activity. Decreased activity was also detected in the sulfone derivatives $(\mathbf{7 h}-\mathbf{7 j} \mathbf{j})$. Their activities were ten times lesser than those of the sulfide derivatives. In the tyrosinase assay, the sulfide linkage is also a critical factor along with the kojic acid moiety. Without the sulfide group,
Table 2. Depigmenting activities of compound $\mathbf{7 b}$, kojic acid, and arbutin

\begin{tabular}{cccc}
\hline Compound & Concentration & $\begin{array}{c}\text { Melanin } \\
\text { production (\%) }\end{array}$ & $\begin{array}{c}\text { Cell viability } \\
(\%)\end{array}$ \\
\hline $7 \mathbf{b}$ & $2 \mu \mathrm{M}$ & 79.99 & 98.76 \\
& $4 \mu \mathrm{M}$ & 72.19 & 100.02 \\
Kojic acid & $8 \mu \mathrm{M}$ & 66.81 & 99.24 \\
Arbutin & $8 \mu \mathrm{M}$ & - & 102.01 \\
\hline
\end{tabular}

- : Not effective.

the kojic acid moiety may not bind tightly to the active site or other essential parts of tyrosinase. The additional oxygen groups in the sulfoxides and sulfones had an effect on conformational changes (Fig. 2).

After evaluating the tyrosinase inhibitory activity, we selected compound $\mathbf{7 b}$ as a candidate for an effective depigmenting agent and evaluated its inhibitory potency against melanin formation. Compound $\mathbf{7 b}$ was assayed for its cytotoxicity and inhibitory activity on a murine melanocyte cell line. The concentrations used $(2 \mu \mathrm{M}, 4 \mu \mathrm{M}$, and $8 \mu \mathrm{M})$ did not have any significant effect on cell viabilities.

The production of melanin decreased by approximately $33.19 \%$ upon treatment by compound $7 \mathbf{b}$ at a concentration of $8 \mu \mathrm{M}$. However, at the same concentration, kojic acid and arbutin had no effect on melanin production. Thus, compound 7b is more effective than kojic acid and arbutin in inhibiting melanin production.

In conclusion, we synthesized a series of kojic acid thioether derivatives (7a-7d), sulfoxide derivatives (7e-7g), and sulfone derivatives $(\mathbf{7} \mathbf{h}-\mathbf{7 j})$. The tyrosinase inhibitory activities for the ten synthesized compounds were evaluated to investigate the structure-activity relationship. Among them, 2-((4-hydroxyphenylthio)methyl)-5-hydroxy-4H-pyran-4-one (7b) exhibited the most potent inhibitory activity $\left(\mathrm{IC}_{50}=0.54 \mu \mathrm{M}\right)$. The structure of $7 \mathbf{b}$ comprises three main parts: the enolic hydroxyl group, thioether linkage, and 4-hydroxy aromatic ring. Among these, the enolic hydroxyl group and the thioether linkage are more important than the 4-hydroxy aromatic ring with respect to the inhibition of tyrosinase. In the cell based assay, compound $\mathbf{7 b}$ decreased the melanin content in a dose-dependent manner



$7 b$

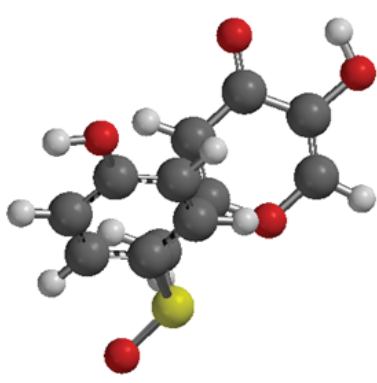

$7 f$

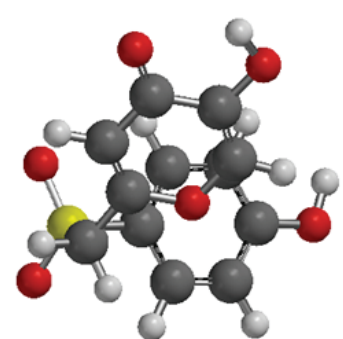

$7 \mathbf{i}$

Figure 2. Energy minimized structures of 7b, 7f, and 7i. Calculations were carried out using Spartan '04 Windows. The global minimum-energy structures were obtained by molecular-mechanics computation and were further refined by DFT computation (B3LYP at the 6-31G* level). 
without cell cytotoxicity. Overall, these results suggest that compound $\mathbf{7 b}$ can be used as an effective skin depigmenting agent.

\section{Experimental Section}

5-Hydroxy-2-((phenylthio)methyl)-4H-pyran-4-one (7a). To a stirred solution of kojyl chloride $\mathbf{5}(4.8 \mathrm{~g}, 30 \mathrm{mmol})$ and TEA $(4.0 \mathrm{~g}, 40 \mathrm{mmol})$ in THF $(100 \mathrm{~mL})$ under $\mathrm{N}_{2}$ was added benzenethiol (3.6 g, $33 \mathrm{mmol}$ ). The reaction mixture was stirred for $10 \mathrm{~h}$ at room temperature and then THF was evaporated in vacuo. The residue was extracted with ethyl acetate $(300 \mathrm{~mL})$, washed with water. The organic layer was dried with anhydrous $\mathrm{MgSO}_{4}$ and concentrated to give a crude product. The resultant was purified by crystallization from ethyl acetate-hexane to give a $7 \mathbf{a}(5.6 \mathrm{~g})$ in $81 \%$ yields.

${ }^{1} \mathrm{H}$ NMR $\left(300 \mathrm{MHz}, \mathrm{DMSO}-d_{6}\right) \delta 9.07(\mathrm{~s}, 1 \mathrm{H}), 7.97(\mathrm{~s}, 1 \mathrm{H})$, 7.26-7.35 (m, 5H), 6.21 (s, 1H), $4.10(\mathrm{~s}, 2 \mathrm{H}) .{ }^{13} \mathrm{C}-\mathrm{NMR}(125$ $\left.\mathrm{MHz}, \mathrm{DMSO}-d_{6}\right) \delta 174.0,164.2,146.1,140.26,140.21,134.3$, 130.2, 129.6, 127.4, 113.1, 112.9, 34.8. FAB MS $(m / e) 235$ $[\mathrm{M}+1]^{+}$.

2-((4-Hydroxyphenylthio)methyl)-5-hydroxy-4H-pyran-4one (7b). ${ }^{1} \mathrm{H}$ NMR $\left(300 \mathrm{MHz}, \mathrm{DMSO}-d_{6}\right) \delta 9.76(\mathrm{~s}, 1 \mathrm{H}), 9.02$ (s, 1H), 7.95 (s, 1H), 7.17 (d, 2H, $J=8.4 \mathrm{~Hz}), 6.68$ (d, 2H, $J=$ $8.4 \mathrm{~Hz}), 5.98(\mathrm{~s}, 1 \mathrm{H}), 3.84(\mathrm{~s}, 2 \mathrm{H}) .{ }^{13} \mathrm{C}-\mathrm{NMR}(125 \mathrm{MHz}$, DMSO$\left.d_{6}\right) \delta 173.9,164.5,158.1,146.0,140.15,140.10,135.03,121.7$, 116.6, 113.05, 112.97, 37.5. FAB MS $(m / e) 251[\mathrm{M}+1]^{+}$.

2-((4-Methoxyphenylthio)methyl)-5-hydroxy-4H-pyran-4one (7c). ${ }^{1} \mathrm{H}$ NMR (300 MHz, DMSO- $\left.d_{6}\right) \delta 9.02$ (s, 1H), 7.96 (s, 1H), 7.29 (d, 2H, J=8.4 Hz), 6.87 (d, 2H, $J=8.4 \mathrm{~Hz}), 6.04$ (s, 1H), 3.92 (s, 2H), 3.69 (s, 3H). ${ }^{13} \mathrm{C}-\mathrm{NMR}\left(125 \mathrm{MHz}, \mathrm{DMSO}-d_{6}\right.$ ) $\delta 173.9,164.4,159.6,146.0,140.19,140.14,134.3,124.0$, $115.2,113.05,112.97,55.7,36.9$. FAB MS $(m / e) 265[\mathrm{M}+1]^{+}$.

2-((4-Hydroxyphenylthio)methyl)-5-methoxy-4H-pyran-4one (7d). ${ }^{1} \mathrm{H}$ NMR (300 MHz, DMSO- $\left.d_{6}\right) \delta 9.71$ (s, 1H), 8.07 $(\mathrm{s}, 1 \mathrm{H}), 7.22(\mathrm{~d}, 2 \mathrm{H}, J=8.4 \mathrm{~Hz}), 6.73(\mathrm{~d}, 2 \mathrm{H}, J=8.4 \mathrm{~Hz}), 5.99(\mathrm{~s}$, 1H), 3.90 (s, 3H), 3.62 (s, 3H). ${ }^{13} \mathrm{C}-\mathrm{NMR}\left(125 \mathrm{MHz}, \mathrm{DMSO}-d_{6}\right)$ $\delta 172.9,164.5,158.1,148.2,139.87,139.84,134.9,121.7,116.6$, 113.95, 113.88, 56.6, 37.4. FAB MS (m/e) $265[\mathrm{M}+1]^{+}$.

5-Hydroxy-2-((phenylsulfinyl)methyl)-4H-pyran-4-one (7e). ${ }^{1} \mathrm{H}$ NMR $\left(300 \mathrm{MHz}, \mathrm{DMSO}-d_{6}\right) \delta 9.20(\mathrm{~s}, 1 \mathrm{H}), 7.86(\mathrm{~s}, 1 \mathrm{H})$, 7.60-7.48 (m, 5H), 6.13 (s, 1H), 4.32 (d, 1H, J=13.5 Hz), 4.15 $(\mathrm{d}, 1 \mathrm{H}, J=13.5 \mathrm{~Hz}) .{ }^{13} \mathrm{C}-\mathrm{NMR}\left(125 \mathrm{MHz}, \mathrm{DMSO}-d_{6}\right) \delta 173.5$, 157.9, 146.4, 142.9, 140.99, 140.45, 129.8, 124.7, 124.4, 116.12, 115.92, 58.7. FAB MS $(m / e) 251[\mathrm{M}+1]^{+}$.

2-((4-Hydroxyphenylsulfinyl)methyl)-5-hydroxy-4H-pyran4-one (7f). ${ }^{1} \mathrm{H}$ NMR (300 MHz, DMSO- $\left.d_{6}\right) \delta 10.21$ (s, 1H), 9.18 $(\mathrm{s}, 1 \mathrm{H}), 7.91(\mathrm{~s}, 1 \mathrm{H}), 7.43(\mathrm{~d}, 2 \mathrm{H}, J=8.4 \mathrm{~Hz}), 6.90(\mathrm{~d}, 2 \mathrm{H}, J=$ $8.4 \mathrm{~Hz}), 6.13(\mathrm{~s}, 1 \mathrm{H}), 4.18$ (d, 1H, $J=13.5 \mathrm{~Hz}), 4.10$ (d, $1 \mathrm{H}, J=$ $13.5 \mathrm{~Hz}) .{ }^{13} \mathrm{C}-\mathrm{NMR}\left(125 \mathrm{MHz}, \mathrm{DMSO}-d_{6}\right) \delta 173.6,160.8,158.2$, $146.3,140.43,140.30,131.8,126.8,116.4,115.92,115.74$, 59.2. FAB MS $(m / e) 267[\mathrm{M}+1]^{+}$.

2-((4-Methoxyphenylsulfinyl)methyl)-5-hydroxy-4H-pyran4-one (7g). ${ }^{1} \mathrm{H}$ NMR $\left(300 \mathrm{MHz}, \mathrm{DMSO}-d_{6}\right) \delta 9.20$ (s, 1H), 7.90 $(\mathrm{s}, 1 \mathrm{H}), 7.53(\mathrm{~d}, 2 \mathrm{H}, J=8.4 \mathrm{~Hz}), 7.10(\mathrm{~d}, 2 \mathrm{H}, J=8.4 \mathrm{~Hz}), 6.15$ $(\mathrm{s}, 1 \mathrm{H}), 4.25(\mathrm{~d}, 1 \mathrm{H}, J=13.5 \mathrm{~Hz}), 4.13(\mathrm{~d}, 1 \mathrm{H}, J=13.5 \mathrm{~Hz}), 3.81$ $(\mathrm{s}, 3 \mathrm{H}) .{ }^{13} \mathrm{C}-\mathrm{NMR}\left(125 \mathrm{MHz}, \mathrm{DMSO}-d_{6}\right) \delta 173.6,156.4,146.6$, $140.8,140.7,138.5,134.9,129.8,128.5,117.00,116.85,59.1$,

\subsection{FAB MS, m/e $281[\mathrm{M}+1]^{+}$}

5-Hydroxy-2-((phenylsulfonyl)methyl)-4H-pyran-4-one (7h). ${ }^{1} \mathrm{H}$ NMR $\left(300 \mathrm{MHz}, \mathrm{DMSO}-d_{6}\right) \delta 9.32(\mathrm{~s}, 1 \mathrm{H}), 7.96(\mathrm{~s}$, 1H), 7.65-7.84 (m, 5H), $6.22(\mathrm{~s}, 1 \mathrm{H}), 4.83(\mathrm{~s}, 2 \mathrm{H}) .{ }^{13} \mathrm{C}-\mathrm{NMR}$ $\left(125 \mathrm{MHz}, \mathrm{DMSO}-d_{6}\right) \delta 173.6,156.4,146.6,140.82,140.73$, $138.5,129.9,128.50,128.40,117.0,116.8,59.1$. FAB MS (m/e) $267[\mathrm{M}+1]^{+}$.

2-((4-Hydroxyphenylsulfonyl)methyl)-5-hydroxy-4H-pyran-4-one (7i). ${ }^{1} \mathrm{H}$ NMR (300 MHz, DMSO-d 6 ) $\delta 10.75$ (s, $1 \mathrm{H}), 9.29(\mathrm{~s}, 1 \mathrm{H}), 7.98(\mathrm{~s}, 1 \mathrm{H}), 7.62(\mathrm{~d}, 2 \mathrm{H}, J=8.4 \mathrm{~Hz}), 6.95$ (d, $2 \mathrm{H}, J=8.4 \mathrm{~Hz}), 619(\mathrm{~s}, 1 \mathrm{H}), 4.68(\mathrm{~s}, 2 \mathrm{H}) .{ }^{13} \mathrm{C}-\mathrm{NMR}(125 \mathrm{MHz}$, DMSO- $\left.d_{6}\right) \delta 173.6,163.1,156.8,146.6,140.7,130.9,128.2$, 116.7, 116.2, 59.5. FAB MS $(m / e) 283[\mathrm{M}+1]^{+}$.

2-((4-Methoxyphenylsulfonyl)methyl)-5-hydroxy-4H-pyran-4-one (7j). ${ }^{1} \mathrm{H}$ NMR $\left(300 \mathrm{MHz}, \mathrm{DMSO}-d_{6}\right) \delta 9.31(\mathrm{~s}, 1 \mathrm{H})$, $7.98(\mathrm{~s}, 1 \mathrm{H}), 7.74(\mathrm{~d}, 2 \mathrm{H}, J=8.4 \mathrm{~Hz}), 7.72(\mathrm{~d}, 2 \mathrm{H}, J=8.4 \mathrm{~Hz})$, $6.22(\mathrm{~s}, 1 \mathrm{H}), 4.75(\mathrm{~s}, 2 \mathrm{H}), 3.86(\mathrm{~s}, 3 \mathrm{H}) .{ }^{13} \mathrm{C}-\mathrm{NMR}(125 \mathrm{MHz}$, DMSO- $\left.d_{6}\right) \delta 173.6,164.1,156.7,146.6,140.7,130.8,130.1$, 116.8, 115.1, 59.4, 56.3. FAB MS $(m / e) 297[\mathrm{M}+1]^{+}$.

Mushroom tyrosinase assay. Mushroom tyrosinase, L-tyrosine were purchased from Sigma Chemical. The reaction mixture for mushroom tyrosinase activity consisted of $150 \mu \mathrm{L}$ of $0.1 \mathrm{M}$ phosphate buffer ( $\mathrm{pH}$ 6.5), $3 \mu \mathrm{L}$ of sample solution, $8 \mu \mathrm{L}$ of mushroom tyrosinase $(2,100$ unit/mL, $0.05 \mathrm{M}$ phosphate buffer at $\mathrm{pH}$ 6.5), and $36 \mu \mathrm{L}$ of $1.5 \mathrm{mM}$ L-tyrosine. Tyrosinase activity was determined by reading the optical density at $490 \mathrm{~nm}$ on a microplate reader (Bio-Rad 3550, Richnmond, CA, U.S.A.) after incubation for $20 \mathrm{~min}$ at $37{ }^{\circ} \mathrm{C}$. The inhibitory activity of the sample was expressed as the concentration that inhibits $50 \%$ of the enzyme activity $\left(\mathrm{IC}_{50}\right)$.

Cell culture. Murine melan-a melanocytes were originally derived from C57BL/6 J (black, a/a) mice, a kind gift from Prof. Dorothy C. Bennett (St. George's Hospital, London, U.K.). Melan-a cells were cultured in RPMI 1640 medium containing $10 \%$ heat-inactivated FBS, 100 units/mL of penicillin, $100 \mu \mathrm{g} /$ $\mathrm{mL}$ of streptomycin, and $200 \mathrm{nM}$ of phorbol 12-myristate 13acetate (TPA) at $37^{\circ} \mathrm{C}$ in $10 \% \mathrm{CO}_{2}$. The culture medium was changed twice every week, and the cells were subcultured once a week.

Measurements of cell viability. To evaluate the effects of kojic acid derivatives on cell viability, the percentages of viable melan-a cells were determined using a modified crystal violet assay. ${ }^{9}$ After removing the medium from each well, the cells were washed with PBS and stained with $0.1 \%$ crystal violet in $10 \%$ ethanol for $5 \mathrm{~min}$ at room temperature. The cells were then rinsed four times with distilled water, and crystal violet retained by adherent cells was extracted with $95 \%$ ethanol at room temperature for $10 \mathrm{~min}$. Crystal violet absorption was measured at $590 \mathrm{~nm}$ (Molecular Devices Co., Sunnyvale, CA, U.S.A.).

Measurements of melanin content. The melanin content was measured using the method reported by Hosoi et al. with a slight modification. ${ }^{10}$ The cells $\left(2 \times 10^{5}\right.$ cells $\left./ \mathrm{mL}\right)$ were seeded into 24-well plates and the test compounds were added in triplicate. The medium was changed daily and after $4 \mathrm{~d}$ of culture, the cells were lysed with $1 \mathrm{~mL}$ of $1 \mathrm{~N} \mathrm{NaOH}$. Then $200 \mu \mathrm{L}$ of each crude cell extract was transferred into 96-well plates. The relative melanin content was measured at $400 \mathrm{~nm}$ with a 
microplate reader (Molecular Devices).

Acknowledgments. This work was supported by a grant from the Kyung Hee University in 2009 (KHU-20090745).

\section{References}

1. Marmol, V. D.; Beermann, F. FEBS Lett. 1996, 381, 165.

2. Gupta, A. K.; Gover, M. D.; Nouri, K. N.; Taylor, S. J. Am. Acad. Dermatol. 2006, 55, 1048.

3. Dalton, S. R.; Gardner, T. L.; Libow, L. F.; Elston, D. M. J. Am. Acad. Dermatol. 2005, 52, 859.

4. a) Briganti, S.; Camera, E.; Picardo, M. Pigment Cell Res. 2003,
16, 101. b) Smth, C. J.; O’Hare, K. B.; Alle, J. C. Pigment Cell Res. 1988, 1,386 .

5. a) Hori, I.; Nihei, K.; Kubo, I. Phytother. Res. 2004, 18, 475. b) Maeda, K.; Fukuda, M. J. Pharmacol. Exp. Ther. 1996, 276, 765.

6. Ohyama, Y.; Mishima, Y. Fragrance J. 1990, 6, 53.

7. Kodokawa, J.; Nishikura, T.; Muraoka, R.; Tagaya, H.; Fukuoka, N. Synth. Commun. 2003, 33, 1081.

8. Rho, H. S.; Baek, H. S.; Ahn, S. M.; Kim, D. H.; Chang, I. S. Bull. Korean Chem. Soc. 2008, 29, 1569.

9. Dooley, T. P.; Gadwood, R. C.; Kilgore, K.; Thomasco, L. M. Skin Pharmacol. 1994, 7, 188.

10. a) Hosoi, J.; Abe, E.; Suda, T.; Kuroki, T. Cancer Res. 1985, 45, 1474. b) Cho, Y.; Kim, K.-H.; Shim, J.-S.; Hwang J.-K. Biol. Pharm. Bull. 2008, 31, 986. 